\title{
A Note on Terminology
}

A number of different labels have been used over the years to distinguish the various ethnic groups living in Texas. In this book, such expressions are used according to the following definitions:

Anglo: any white, English-speaking, non-Mexican American. casta: a person of mixed Spanish, Indian, and African ancestry. creole: English form of criollo.

criollo: a person of Spanish ancestry born in the New World.

Isleña: female descendant of any of several families that came to

San Antonio from the Canary Islands in I73I.

mestizo: a person of mixed Spanish and Indian ancestry.

Mexican: a person from Mexico, or a person of Mexican ancestry.

(No attempt is made to distinguish Mexican citizens, Mexican immigrants to Texas, and Texan or American citizens of Mexican ancestry.)

Mexicana: a Mexican or Mexican American woman.

Mexicano: used interchangeably with Mexican.

pelado: a contemptuous term used by Anglos in reference to what they considered the lowest class of Mexicans. peninsular: Spaniard (from the Iberian Peninsula). Tejana: feminine form of Tejano.

Tejano: a Mexican resident of Texas, whether born in Mexico or the United States (or Republic of Texas).

Texan: an Anglo resident of Texas.

Texian: term of self-reference used by Anglos during the early years of residence in Texas. 
There is a report in camp that our company has been ordered to Corpus Christi which I hope is so. I am getting rather tired of the Rio Grande and the greasers, of all the contemptable, despecable people on Earth the greasers in my estimation are the lowest, meaner even than the Cummanche. They are ugly, theiving, rascally in every way and to be educated only makes a greaser the grander rascal. I think the whole nation ought to be peoned rich and poor, they would make the best plantation hands in the world. They fear and respect authority and are a great deal moore humble and less inteligent than our negroes.

(Letter of George L. Robertson to his sister, from Rancho Palmito, March 26, I864;

George L. Robertson Papers, I839-1869, University of Texas Archives, Austin) 